\title{
白金担持カーボンーポリイオンコンプレックスで構成された 電極触媒層の電気化学的キャラクタリゼーション
}

\author{
川口 俊輔 ${ }^{1}$, 鎌田 雅也 ${ }^{1}$, 山田 明文 ${ }^{1}$, 梅 田 実 $^{\circledR 1}$
}

\author{
Electrochemical characterization of $\mathrm{Pt} / \mathrm{C}$ and a polyelectrolyte \\ complex-based catalyst layer
}

\begin{abstract}
Syunsuke Kawaguchi ${ }^{1}$, Masaya Kamada ${ }^{1}$, Akifumi Yamada $^{1}$ and Minoru UmedA ${ }^{1}$
${ }^{1}$ Department of Chemistry, Nagaoka University of Technology, 1603-1, Kamitomioka-cho, Nagaoka-shi, Niigata $940-2188$
\end{abstract}

(Received 6 May 2004, Accepted 20 July 2004)

\begin{abstract}
The electrocatalyst layer of polymer electrolyte fuel cells(PEFCs) formed a three-phase interface by using a mixture of $\mathrm{Pt} / \mathrm{C}$ and a proton-conductive polymer. In the case where Nafion was used as a proton-conductive polymer, some extent of platinum particles of $\mathrm{Pt} / \mathrm{C}$ were covered by a insulation property cluster of Nafion; therefor, an efficient formation of the threephase interface was not achieved. In the present study, polyelectrolyte complex(PEC) was used with $\mathrm{Pt} / \mathrm{C}$ instead of Nafion. PEC, which has a small cluster size, could be expected not to cover the Pt particle. An electrode catalyst layer consisting of the $\mathrm{Pt} / \mathrm{C}$ and a PEC was prepared on an Au flag electrode. The platinum utilization efficiency was measured by cyclic voltammetry. As a result, it was found that the Pt surface area of the Pt/C-PEC was 1.5-times larger than that of Pt/C-Nafion.
\end{abstract}

Keywords : polyelectrolyte complex; Pt/C; electrocatalyst layer; Nafion; polymer electrolyte fuel cell.

\section{1 緒言}

近年，内燃機関に代わるエネルギー源として，低環境負 荷や発電効率の高さから燃料電池が次世代の電源として大 きく注目されている.中でも固体高分子形燃料電池 (polymer electrolyte fuel cell, PEFC) は, そのコンパク トかつ軽量な構造から, 携帯機器用電源として期待を集め ている1)2).

PEFC の心臓部は，プロトン伝導性を有する高分子膜と， 白金系の触媒を使用した電極触媒層を有する膜一電極接合 体 (membrane electrode assembly, MEA) であり, 現在 電極触媒層には白金担持カーボン $(\mathrm{Pt} / \mathrm{C})$ とプロトン伝 導性のナフィオン樹脂とで構成された触媒層が主に使用さ

\footnotetext{
${ }^{1}$ 長岡技術科学大学工学部：940-2188 新潟県長岡市上富岡町 1603- 1
}

れている. $\mathrm{Pt} / \mathrm{C}$ は, 白金微粒子をカーボン担体上に分散 させることで白金表面積を大きくできるため，高価な貴金 属触媒の使用量を低減させることが可能となる。また, $\mathrm{Pt} / \mathrm{C}$ とナフィオンの混合使用により, 反応種（水素ガス, 酸素ガス，メタノール等)，電子，プロトンが同時に反応 に関与できる三相界面の形成割合が増大した ${ }^{3) \sim 5)}$.

しかしながら，ナフィオンはテフロンに類似した主鎖が 集まった疎水性領域と，イオン交換基を有する側鎖が集ま った親水性領域から成る構造を持つため ${ }^{6)}$, Fig. 1 a に示 すとおり，その疎水性領域に覆われてしまった白金微粒子 は，三相界面を形成することができず反応に関与できな $\omega^{7)}$. そのため, 電極触媒層の白金利用率は十分とは言い 難い。この改善策として，本論文では Fig. 1 b に示すよう な構成を提案する.すなわち $\mathrm{Pt}$ 微粒子よりも疎水性クラ スターサイズの小さいプロトン伝導性高分子膜を採用し 

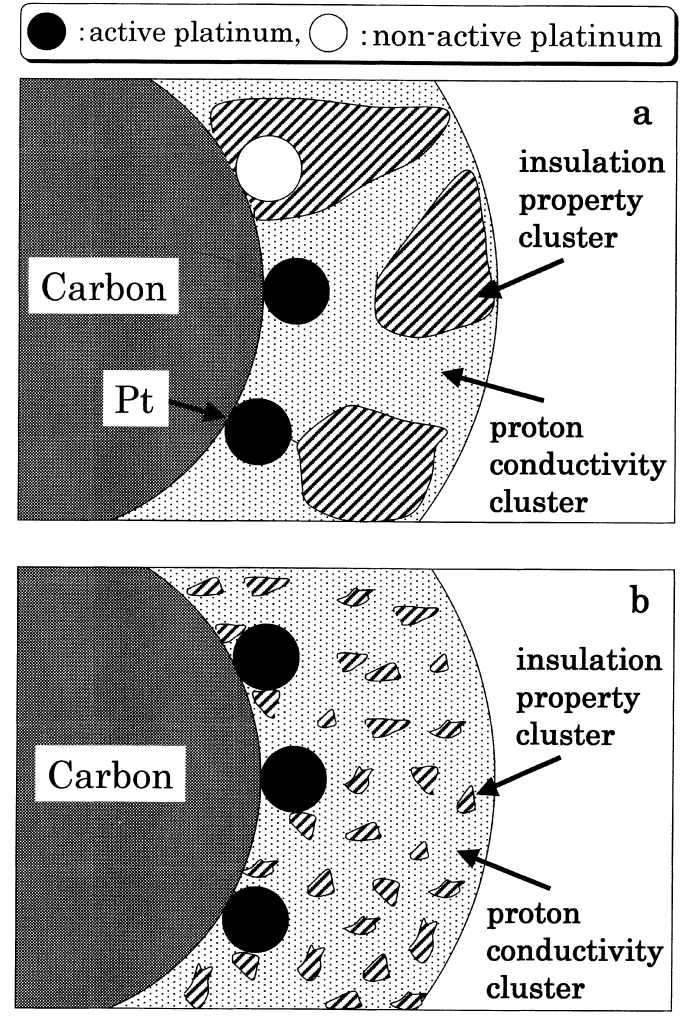

Fig. 1 Schematic illustrations of (a) a conventional $\mathrm{Pt} / \mathrm{C}-\mathrm{Nafion}-\mathrm{b} a \mathrm{sed}$ electrode and (b) the proposed $\mathrm{Pt} / \mathrm{C}$-polyelectrolyte complex-based electrode for an efficient three-phase interface formation

$\mathrm{Pt} / \mathrm{C}$ に混合させることで，Pt 微粒子はその疎水性クラス ターに隠蔽されることなく, 三相界面を形成できると考え る.このような機能を持つ高分子材料として, ポリイオン コンプレックス膜（PEC）を採り上げる ${ }^{8)}$.しかし，一般 にPEC は強酸を含んだ溶媒にのみ溶解するため簡便に扱 うことができない ${ }^{99}$. 触媒層を簡便に形成するためには, $\mathrm{Pt} / \mathrm{C}$ とプロトン伝導性高分子膜の溶液塗工が必要である. 中性溶液からの溶液塗工が可能な PEC として, 本研究室 で開発したプレカーサー法を用いたPECを採用すること ができる ${ }^{10)}$ ここの方法によれば，ポリスチレンスルホン酸 （PSS）水溶液とポリエチレンイミン水溶液から, Fig. 2 に 示すプロトン輸送性 PEC 膜を容易に形成することができ る。製膜した PEC は水に不溶で導電率が $9.0 \times 10^{-2} \mathrm{~S} / \mathrm{cm}$ あり, 更に疎水性ユニットのサイズが非常に小さい.

本研究は，白金触媒利用率のより高い電極触媒層を作製 することを目的としており，その方法として Pt/Cにナフ イオン又は PEC を混合させた電極触媒層を作製し，3電 極式電気化学測定により, ナフィオン使用時と PEC 使用 時に扔ける白金利用率の解析・比較検討を行った.

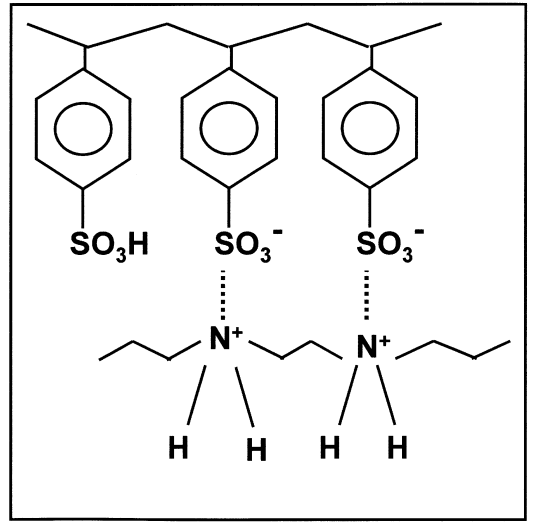

Fig. 2 Schematic structure of polyelectrolyte complex

\section{2 実験方法}

\section{$2 \cdot 1 \mathrm{X}$ 線回析装置}

実験に使用した白金粒子の粒径を得るために, $\mathrm{Pt} / \mathrm{C}$ 触 媒のキャラクタリゼーションとして, 粉末 X 線回折を行 った。X線回折装置 (X-ray diffractometer, XRD, ShimazuXD-D1）を用い, $\mathrm{X}$ 線源に $\mathrm{CuK}_{\alpha}$, 発散スリット $0.3^{\circ}, \mathrm{X}$ 線入射角 $2^{\circ}$ ，管電流・管電圧はそれぞれ 30 $\mathrm{mA} \cdot 40 \mathrm{kV}$ にて解析を行った.

\section{$2 \cdot 2$ ポリイオンコンプレックス膜の作製}

2・2・1 PSSNa のイオン交換＼cjkstart酸性ポリマーとして, ポリスチレンスルホン酸ナトリウム（PSSNa，数平均分子 量：70000）を $10 \mathrm{wt} \%$ 水溶液に調整し，イオン交換樹脂 ビーズ（ムロマチテクノス製 HCR-W2）を添加（重量比, PSSNa/イオン交換樹脂ビーズ $=1 / 10 ）$ した，その液を木 ットスターラーにて約 $40^{\circ} \mathrm{C} ， 30$ 分間かくはんした後，吸 引沪過を行って PSS 水溶液を得た。

$2 \cdot 2 \cdot 2$ キャスト溶液 イオン交換により得られた PSS 水溶液に, 塩基性ポリマーとしてポリエチレンイミン （PEI，数平均分子量： $50000 \sim 100000 ） の 10 \mathrm{wt} . \%$ 水溶液 を加え，モノマーユニット比（SS/EI）が2 となるキャス 卜溶液を調製した。

2・2・3 触媒分散液 キャス卜溶液と $\mathrm{Pt} / \mathrm{C} （ 20 \mathrm{wt} . \%$ $\mathrm{Pt}$ ，Electrochem 製）を任意の割合で混合し，アルコール 水溶液（重量比, 純水/メ夕ノール/2-プロパノール = 1/1/1) を加えた後, 超音波洗浄器を用いて触媒微粒子を 十分に分散させた。また，ナフィオン（5 wt.\% Nafion， Du Pont 製）を含んだ触媒分散液を作製する際，まず純水 にて $\mathrm{Pt} / \mathrm{C}$ を湿らせてからナフィオン溶液を加えた。その 後, それぞれPEC (密度: $1.29 \mathrm{~g} / \mathrm{cm}^{3}$ ) とナフィオン (密度: $2.1 \mathrm{~g} / \mathrm{cm}^{3}$ ) を同体積量含んだ $\mathrm{Pt} / \mathrm{C}$ 分散液を作製 


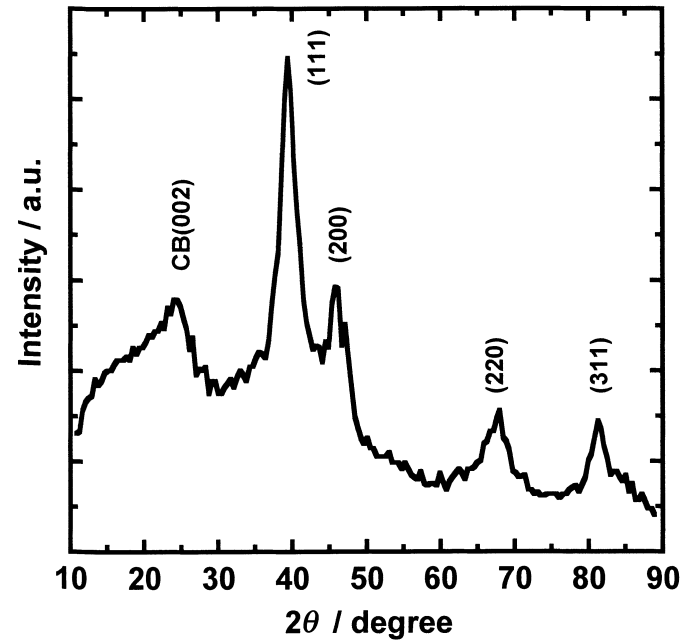

Fig. 3 X-ray diffraction patterns of $\mathrm{Pt} / \mathrm{C}(20 \mathrm{wt} . \% \mathrm{Pt})$ powder

した.

\section{$2 \cdot 3$ 電極の作製}

直径 $5 \mathrm{~mm}$ の円形金簿シートとリード線となる金線を， アセトンにて洗浄後, スポットウェルダーを用いて溶接し た。得られた金フラッグ電極（全表面積： $0.40 \mathrm{~cm}^{2}$ ) を $3 \mathrm{M}$ 硝酸に 1 昼夜浸漬し純水にて 3 回洗浄後, 乾燥させ触 媒分散液を塗布した。

金フラッグ電極上に触媒分散液を塗布する際，PEC・ ナフィオン共にディップコート法を用いた。PECを含ん だ電極は自然乾燥後， $0.5 \mathrm{M}$ 硫酸により 1 分間の酸処理を 行った。またナフィオンを含んだ電極は約 $140^{\circ} \mathrm{C} に 20$ 分間真空乾燥後，酸処理を行った。

\section{$2 \cdot 4$ 電気化学測定}

測定は 3 電極式で行い, 電位制御及び電流測定はポテ ンショスタットを用いた。作用極に触媒層を塗布した金フ ラッグ電極を用い，参照電極には水銀・硫酸水銀電極，対 極に白金線を使用した。電解液は, 窒素にて 20 分以上バ ブリングを行い脱酸素した $0.5 \mathrm{M}$ 硫酸を用い, 大気圧・常 温下にて測定を行った。

$100 \mathrm{mV} / \mathrm{s}$ で 20 分間多重掃引した後，掃引速度を変化 させ $(2,5,10,20,50 \mathrm{mV} / \mathrm{s})$ サイクリックボルタモグ ラムを測定した。得られたボルタモグラムから水素吸着波 の電荷を計算し，白金表面積の算出に使用した。

\section{3 結果と考察}

$3 \cdot 1 \mathrm{Pt} / \mathrm{C}$ 触媒のキャラクタリゼーション

実験に使用した $\mathrm{Pt} / \mathrm{C}$ の XRD 回折パターンを Fig. 3 に 示す. $2 \theta=25^{\circ}$ において現れたブロードなピークは, カ
ーボンブラックの六方晶構造の（002）面に対応したもの である。その他の XRD 回折パターンは, 白金の面心立方 格子 (face centered cubic, f.c.c.) に起因する回折ピーク であり，典型的な白金の回折パターンを示している ${ }^{11)}$. 高 角度側からそれぞれ f.c.cの（111），（200），(220），(311） 面に対応している。（111）面のピーク半值幅 $\beta_{1 / 2}$ を求め, 以下に示す Scherrer の式 (1) より白金微粒子の粒径を算 出した ${ }^{12)}$.

$$
D_{\mathrm{hkl}} \frac{K \lambda}{\beta_{1 / 2} \cos }
$$

$K$ はシュラー定数 $(K=0.9), \lambda$ は $\mathrm{CuK}_{\alpha}$ 線波長, $\beta_{1 / 2}$ は半值幅, $D_{\mathrm{hkl}}$ は $(\mathrm{hkl})$ に垂直な方向の結晶格子径であ る.XRD 回折パターンから得られた，実験に使用する白 金微粒子の平均粒径は $6.74 \mathrm{~nm}$ である.この值は，後の 白金利用率の計算に使用する.

\section{$3 \cdot 2$ 電気化学特性}

$3 \cdot 2 \cdot 1$ 掃引速度依存性乾燥後 $\mathrm{Pt} / \mathrm{C}$ に対する高分 子含有体積が同じになるように，PECとナフイオンをそ れぞれ含んだ触媒層塗工液から金フラッグ電極上に触媒層 を形成し，サイクリックボルタモグラムの測定を行った。 Pt/C-PEC 電極のボルタモグラムを Fig. $4 \mathrm{a}$ に, Pt/C-ナ フィオン電極のボルタモグラムを Fig. $4 \mathrm{~b}$ にそれぞれ示 す.どちらも掃引速度 $2 \mathrm{mV} / \mathrm{s}$ の結果である. Pt/C-PEC 及び $\mathrm{Pt} / \mathrm{C}$-ナフィオン電極の両者において，白金電極の 示す典型的なボルタモグラムに近い形状が観測される ${ }^{13)}$. このボルタモグラムの斜線部面積から, 水素吸着波の電荷 $\left(Q_{\mathrm{ads}}\right)^{14) 15)}$ 及び水素脱着波の電荷 $\left(Q_{\mathrm{des}}\right)$ を求め，その平 均值 $(Q)$ と式 $(2)$ より白金表面積 $\left(S_{\mathrm{Pt}}\right)$ を算出した.

$$
S_{\mathrm{Pt}}\left(\mathrm{cm}^{2}\right)=\frac{Q(\mathrm{C})}{210 \times 10^{-6}\left(\mathrm{C} / \mathrm{cm}^{2}\right)}
$$

電極触媒中の有効な $S_{\mathrm{Pt}}$ を正確に求めるため, 掃引速度 依存性について行った実験結果を Fig. 5 に示す. PEC，ナ フィオンの両者において, 掃引速度が遅くなるにつれて $S_{\mathrm{Pt}}$ が増大する傾向が見られた。また $5 \mathrm{mV} / \mathrm{s}$ 以下の掃引 速度では， $S_{\mathrm{Pt}}$ はほぼ一定であった。掃引速度を変化させ てもボルタモグラムに変化がない場合，電極反応速度に対 し膜中のプロトン拡散速度が十分であると言える。つまり この掃引速度依存性が観測できる領域は，膜中でのプロト ン拡散が影響しているものと考察される。掃引速度が遅い 場合，プロトンが膜中の反応場である白金微粒子に到達す る時間が十分にあるが，掃引速度が速い場合は，膜中のプ ロトン拡散移動が追いつかず白金微粒子まで到達できない 

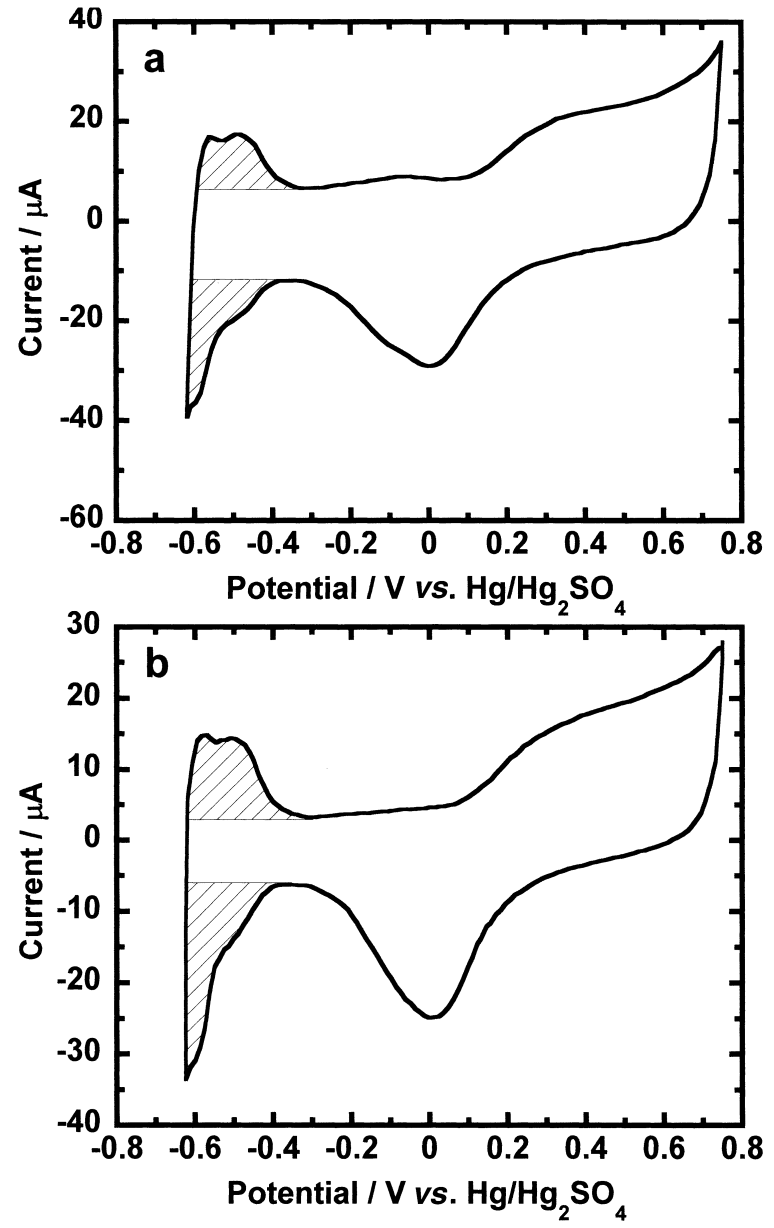

Fig. 4 Cyclic voltammograms at (a) Pt/C-polyelectrolyte complex/Au flag electrode. (b) Pt/CNafion/Au flag electrode in $0.5 \mathrm{M} \mathrm{H}_{2} \mathrm{SO}_{4}$

Scan rate: $2 \mathrm{mV} / \mathrm{s}$

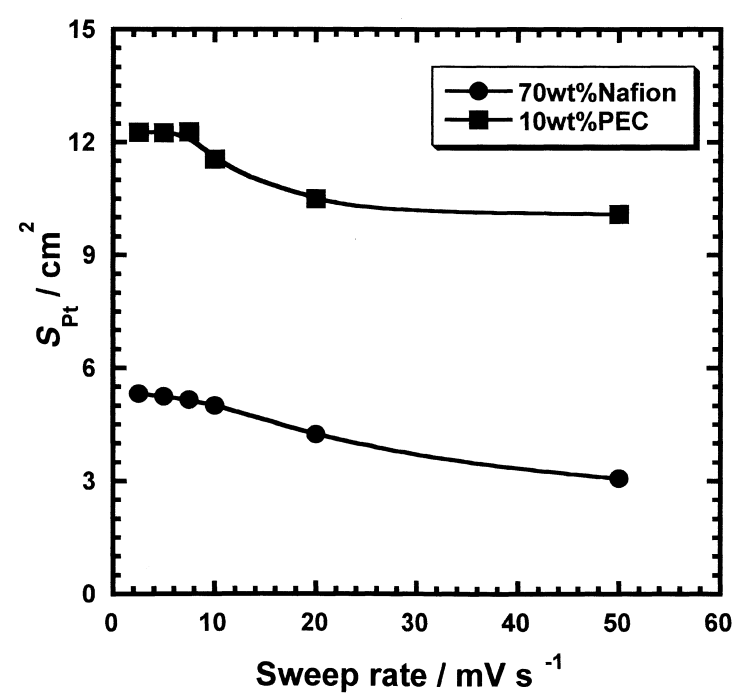

Fig. 5 Pt surface area dependence on potential sweep rate
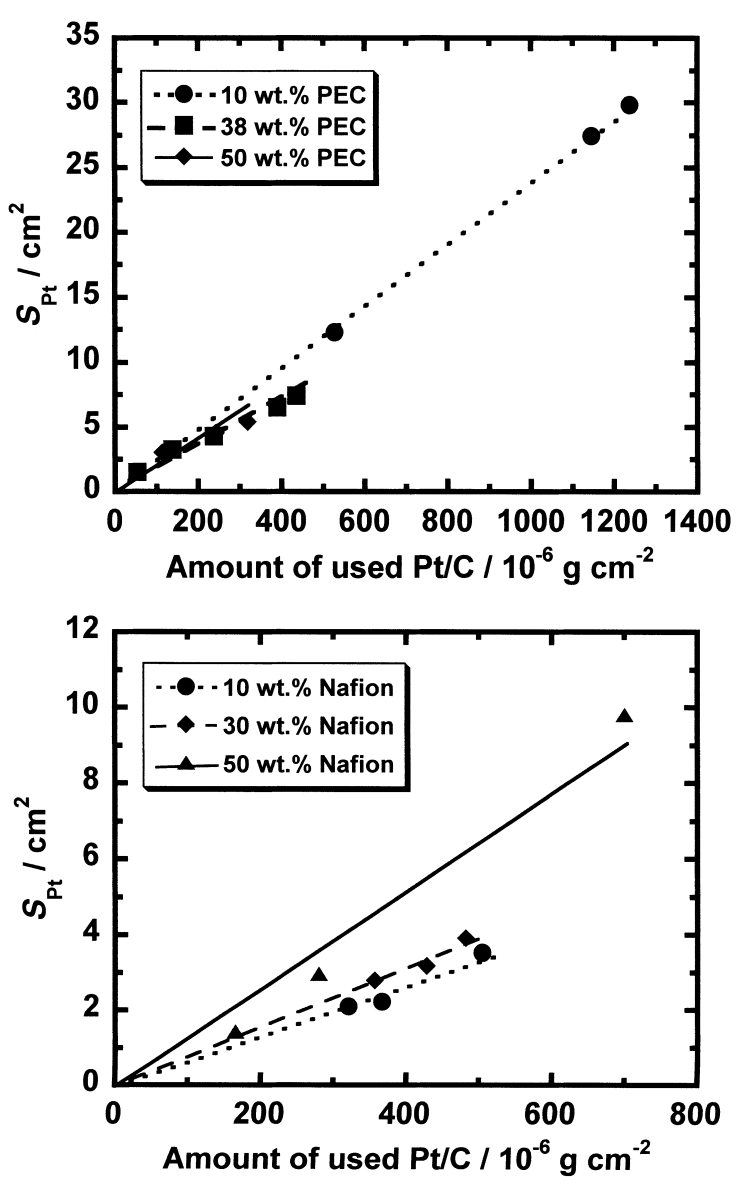

Fig. 6 Amount of deposited Pt/C vs. Pt surface area Proton conductive polymer is a: PEC; $\mathrm{b}$ : Nafion

ものと推測される。これらを考慮し，以後の実験において プロトン拡散の影響を最小限に抑えた状態で $S_{\mathrm{Pt}}$ を求める ため，掃引速度を $2 \mathrm{mV} / \mathrm{s}$ と定めた。

$3 \cdot 2 \cdot 2$ 触媒とポリマーの比率の検討 触媒分散液中 の触媒とポリマーの比率を調整し, $\mathrm{Pt} / \mathrm{C}-\mathrm{PEC}$ 電極と $\mathrm{Pt} / \mathrm{C}$-ナフィオン電極をそれぞれ作製した。 また触媒層中 のポリマーの比率は式（３）のように定義した.

Polymer ratio (wt.\%)

$$
\text { Polymer mass }(\mathrm{g})
$$

作製したそれぞれの作用極を使用し，3・2・1 と同様にサ イクリックボルタンメトリー測定を行った。得られたボル タモグラムから算出した $S_{\mathrm{Pt}}$ と $\mathrm{Pt} / \mathrm{C}$ 量の関係を Fig. 6 に 示す. $\mathrm{Pt} / \mathrm{C}-\mathrm{PEC}$ 電極の結果を Fig. $6 \mathrm{a}$ に, Pt/C-ナフィ オン電極の結果を Fig. $6 \mathrm{~b}$ にそれぞれ示す. PEC，ナフィ オン両者において, いずれの場合もほぼ原点を通過する直 線関係が得られる。もしも得られた結果が直線ではなく, ある $\mathrm{Pt} / \mathrm{C}$ 量を境に $S_{\mathrm{Pt}}$ が一定になったとすれば，それは 


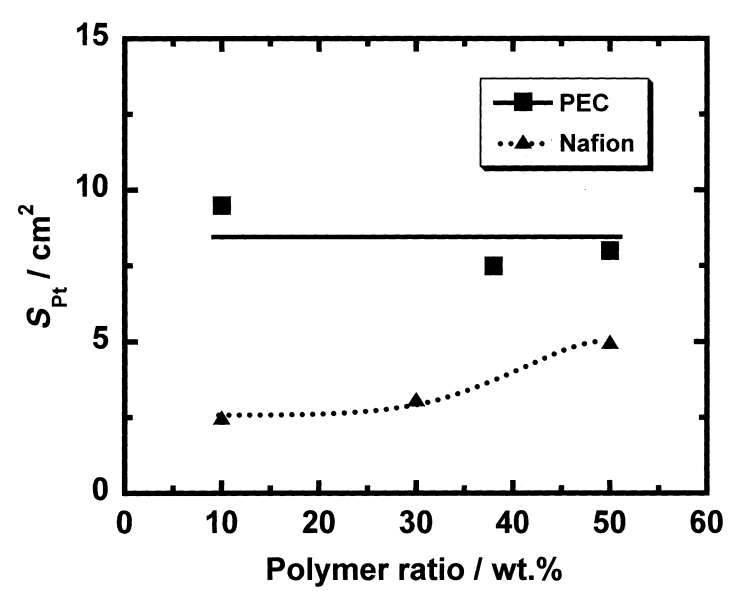

Fig. 7 Pt surface area dependence on polymer ratio

反応に関与できない白金触媒が存在することを意味する. しかし, Fig. 6 で直線関係が得られた結果は, 堆積した $\mathrm{Pt} / \mathrm{C}$ 量に比例して反応場である $S_{\mathrm{Pt}}$ が増加したことを示 し，白金触媒層膜厚による鿵蔽効果がないことを示してい る.

Fig. 6 に打いて, Pt/C 堆積量が $400 \mu \mathrm{g} / \mathrm{cm}^{2}$ のときの, ポリマー比率と $S_{\mathrm{Pt}}$ の関係を Fig. 7 に示す. PEC はポリマ 一の比率に影響されることなく， $S_{\mathrm{Pt}}$ がほぼ一定となった。 この結果は, 膜内部で三相界面が常に一定量形成されてい ることを示している。一方，ナフィオンはポリマーの比率 が高くなるにつれ $S_{\mathrm{Pt}}$ が増加する傾向が見られた。これは ナフィオン含有量の増加に伴い, 膜内部に三相界面が多く 形成された結果と考えられる ${ }^{3)}$. しかし，ナフイオンはポ リマーが一定比率を超えると，その活性が低下することが 報告されている゙). すなわち, $\mathrm{Pt} / \mathrm{C}$ とポリマーの比率に最 適值が存在することから, 三相界面の形成状態がポリマー 比率により変化し, 触媒利用率に大きく影響を与えている と言える。

\section{3・2・3 PEC とナフィオン使用時の白金表面積比較}

Fig. 6 から, PEC $(38$ wt.\%) と同体積のナフィオン使用 量（50 wt.\%）時の結果を比較するため，各々の $\mathrm{Pt} / \mathrm{C}$ 塗 工量に対する $S_{\mathrm{Pt}}$ の関係を Fig. 8 に示す。一方，白金の利 用率の計算式を式 $(4)$ に示す.

\section{白金利用率 $(\%)=$}

$$
\frac{S_{\mathrm{Pt}}\left(\mathrm{cm}^{2}\right)}{\text { 見掛けの白金表面積の合計 }\left(\mathrm{cm}^{2}\right)} \times 100
$$

この式より两者の白金利用率を計算すると, PEC は $22.5 \%$ ，ナフィオンは $15.0 \%$ である.ナフィオン使用時 と比較して PEC 使用時は約 1.5 倍に白金表面積の増加が 見られる。これは $\mathrm{Pt} / \mathrm{C}-\mathrm{PEC}$ 電極触媒層中では Fig. 1 に

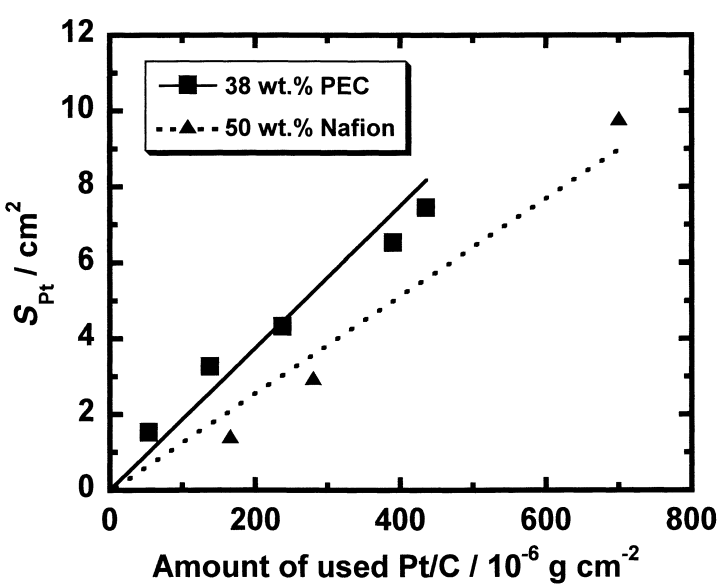

Fig. 8 Amount of deposited Pt/C vs. Pt surface area Used polymer: 38 wt.\% PEC and 50 wt. \% Nafion

示すように，疎水性領域にて完全に隠蔽されてしまう白金 微粒子が少ないものと推測される。つまり PECの持つ疎 水性領域は, ナフィオンのそれに比べ小さいと考えられ る.

$$
4 \text { ま と め }
$$

$\mathrm{Pt} / \mathrm{C}$ に疎水性クラスターサイズがナフィオンよりも小 さいと考えられる PEC をプロトン伝導性高分子膜として 採用することで，燃料電池用電極触媒層中の白金利用率の 向上を検討したＰEC $\mathrm{Pt} / \mathrm{C}$ 微粒子と混合させて電極触 媒層を作製し，電気化学測定により従来タイプのナフィオ ンと比較検討を行った。その結果，PEC と同体積量のナ フィオンを電極触媒に使用した場合，PEC はナフィオン と比較して約 1.5 倍の白金表面積が増加することを見出し た。

本研究の一部は, 文部科学省科学研究費補助金基盤研究 (B) (2) (No. 16350098)，新エネルギー・産業技術総合開発機構「固体高 分子形燃料電池要素技術等のプロジェクト」の助成を得て行われ た。

\section{文献}

1) H. P. Dhar: J. Electroanal. Chem., 357, 237 (1993).

2) M. Jacoby: Chem. Eng. News (June, 1999).

3) E. Passalacqua, F. Lufrano, G. Squadrito, A. Patti, L. Giorgi: Electrochim. Acta, 46, 799 (2001).

4) A. Havranek, K. Klafki, K. Wippermann: Abstract of the 199th ESS Meeeting, 87, Washington, March, 2529 (2001).

5) R. C. Alkire, H. Gerisher, D. M. Kolb, C. W. Tobias : "Advances in Electrochemical Science and Engeneering", Vol. 5, p. 231 (1997), (Wiley, New York).

6) Z. Ogumi, T. Kuroe, Z. Takehara: J. Electrochem. Soc., 132, 2601 (1985).

7) 人見周二, 安田秀雄, 山地正矩：第 40 回電池討論 
会講演要旨集, p. 167 (1999).

8) H. F. Mark, N. M. Bikales, C. G. Overberger, G. Menges: "Encyclopedia of Polymer Science and Engineering: Polyelectrolyte Complexes", p. 720 (1988), (Wiley-Interscience, New York).

9) H. Akahoshi, S. Toshima, K. Itaya: J. Phys. Chem., 85, 818 (1981).

10) 鎌田雅也，梅田 実，山田明文，内田 勇：表面技 術, 54, 198 (2003).

11) T. M. Kahmer, W. F. McClune, S. N. Kabekkodu, H.
E. Clark: "Powder Diffraction File Alphabetical Indexes Inorganic Phases", p. 976 (1998).

12) 仁田勇監修：“X 線結晶学”(上)，(下)，(1961)，(丸 善).

13) 古屋長一: “新編 電気化学測定法”, 電気化学会編, p. 1 (1998), (電気化学会)

14) M. Watanabe, K. Makita, H. Usami, A. Motoo: J. Electroanal. Chem., 197, 195 (1986).

15) A. J. Bard, L. R. Faulkner: "Electrochemical Methods", 2nd Ed., p. 166 (2001), (Wiley, New York).

\section{要旨}

固体高分子形燃料電池用電極触媒層は，白金担持カーボン $(\mathrm{Pt} / \mathrm{C})$ とプロトン伝導性高分子の混合使用 により三相界面を形成している。プロトン伝導膜としてナフィオンを使用した場合，ナフィオンの疎水性ク ラスターに覆われた白金微粒子は，三相界面を形成せず反応に関与できないため，電極触媒中の白金利用率 は十分に高くはない，そこで，ナフイオンに代わるプロトン伝導膜として，ポリイオンコンプレックス膜 （PEC）を採用し $\mathrm{Pt} / \mathrm{C}$ に混合させた。 PEC は疎水性クラスターサイズが小さく白金微粒子を隠蔽しにくい ため，白金の利用率がナフィオンよりも高くなると考えられる。本研究では金基盤電極上に $\mathrm{Pt} / \mathrm{C}$ と $\mathrm{PEC}$ を混合させた電極触媒層を作製し， 3 電極式電気化学測定により， $\mathrm{Pt} / \mathrm{C}$ とナフィオンを用いた場合に対す る白金利用率の比較検討を行った。その結果，ナフィオンと同体積の PEC を混合した電極では，ナフィオ ン混合時と比較して約 1.5 倍に白金表面積が増加することを見いだした. 